\title{
一般報文
}

\author{
角打組物の圧縮特性に関する研究 \\ 一側面拘束無し条件での復元挙動について-
}

\author{
日本ピラー工業 上田隆久・大谷章夫 \\ 京都工芸綫維大学大学院 阿久津公彦・仲井朝美・濱田泰以
}

\section{Compression Properties of Square Braided Fabric -Recovery properties after flat compression-}

\author{
Takahisa Ueda ${ }^{{ }_{1}}$, Akio Ohtani ${ }^{{ }_{1}}$, Kimihiko Akutsu ${ }^{{ }^{2}}$, Asami Nakai ${ }^{* 2}$ and Hiroyuki Hamada ${ }^{{ }_{2}}$
}

\author{
${ }^{* 1}$ Nippon Piller Packing Co.,Ltd, 11-48 Nonakaminami 2-chome, Yodogawa-ku, Osaka 532-0022, Japan \\ ${ }^{* 2}$ Advanced Fibro-Science, Kyoto Institute of Technology, Matsugasaki, Sakyo-ku, Kyoto 606-8585, Japan
}

\begin{abstract}
In this study, recovery properties of square braided fabric after flat compression were focused. The observation of the cross section with optical microscopy was performed and the mechanism of recovery deformation was clarified. Inside structure of braided fabric and recovery properties were extremely changed at first compression and then tended to converge to stable structure. Recovery ratio kept almost constant value after 2 nd cycle. Recovery of braided fabric was resulted from change in braiding angle of fiber bundle ' $a$ ' and ' $b$ ' and decrease in crimp of fiber bundle.
\end{abstract}

(Received 16 December, 2002; Accepted 26 August, 2003)

\section{1. 緒 言}

各種機器からの内部流体の漏れを止める部品であるグ ランドパッキンには多数本の繊維束を角型断面に組んだ 角打組物が使用されている。このグランドパッキンは圧縮 された状態で使用され、その取り付け方法には 2 平面間で の圧縮である側面を拘束しない条件と、溝内で圧縮する側 面拘束条件の 2 種類がある。

この時に要求される性能は、加圧時に均一に変形するこ と、および密着状態を形成できることである。そして、加 圧力の変化が発生した場合においても、変形して密着状態 を維持する必要がある。すなわち、压縮力に対応する変形 忘答性である圧縮特性と除圧に対する変形忘答性である 復元特性の解明は、漏れを止める性能を改良するために重 要である。このため、前報 [1] においては、側面を拘束 しない条件で絽り返し圧縮負荷試験を行い、圧縮時の荷重 と変位の関係について検討した。さらに未圧縮時と圧縮時 組物の断面観察を行い、角打組物の瀻維束配向状態の変化 と組物圧樎举動の関係について報告した。

そこで本研究では、前報に引き続き側面拘束無し条件で 角打組物の繰り返し压縮負荷試験を行い、特に復元時の荷 重と変位の関係について検討した。さらに未压縮時、圧縮 時および復元時の組物の断面観察を行い、角打組物の復元
挙動と緎維束配向状態の変化の関係を明らかにした。前報 と異なる点は、色の異なる織維束を用いることにより、よ り正確な䋐維束配向状態を容易にかつ正確に得ることが できる手法を採用した点である。

\section{2. 実 臨}

\section{1 供試体の作製}

本研究で採用した角打組物は、前報と同様である。図 1 (a)にその外観写真を示す。組物中の䋐維束配向状態は本 研究においては非常に重要であるため、組機における䋐維 束の軌道について本報にお゙いても述べることにする。図 I（b) は、組機を上方より観察した軌道を示しており、4 䇢 所の軌道は対角線上を移動する経路 a と、対角線に平行な 長方形軌道である経路 bの 2 種類の経路より構成されてい る。

用いた材料はフィラメントの直径 $12 \mu \mathrm{m}$ 、集束本数 5000 フィラメントのアラミド䋐維(HM-1055-7250d ; AKZO)を 2 本引き揃えた繊維束である。なお、本報においては断面観

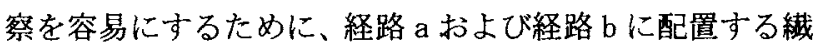
維束のうちの各 2 本には、異なる色に着色した䋐維束を使 用した。この繊維束は、その断面形状を円形と仮定した場 合に、直径が約 $1.3 \mathrm{~mm}$ である。この材料を使用して、組物 
表面に露出している経路 $\mathrm{b}$ の瀻維束と組物長手方向との角 度が $35^{\circ}$ 、平均断面寸法が $10.9 \mathrm{~mm}$ の角型断面を有する紐 状の角打組物を作製した。ここで、平均断面寸法は、組物 の幅と㕌みより断面積を計算した值の平方根である。

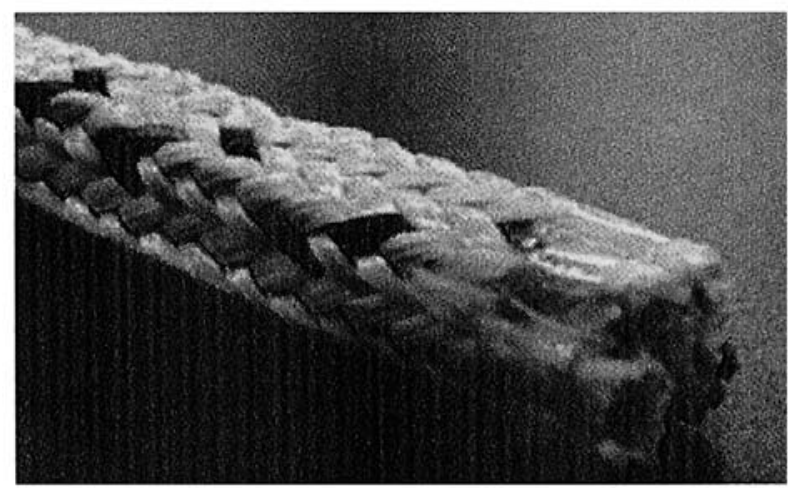

(a)

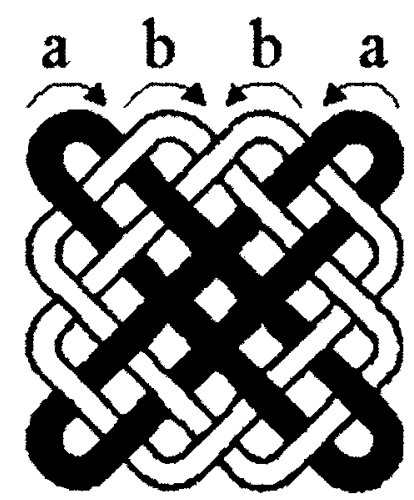

(b)

Fig. 1 (a) Picture of square braided fabric, (b) Path of fiber bundle $\mathbf{a}$ and $\mathbf{b}$.

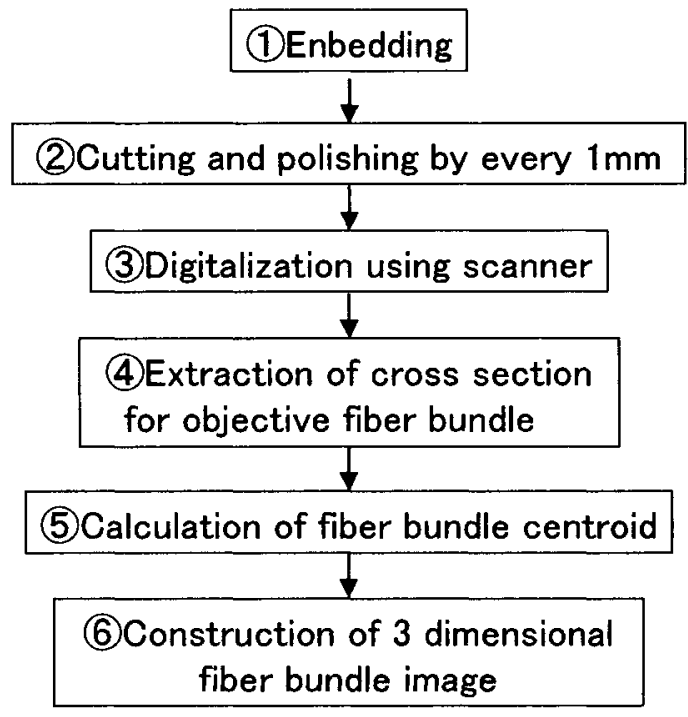

\section{2 圧縮、復元試験}

側面拘束なし条件下での繰り返し圧縮・復元試験は、直 径 $150 \mathrm{~mm}$ の円盤状上に長さ $150 \mathrm{~mm}$ の角打組物を保持し、直 径 $100 \mathrm{~mm} の$ 円盤状圧子を用いて繰り返し行った。試験条件 は前報と同様であり、インストロン万能試験機 (Type4206)

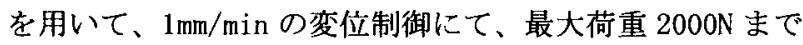
の圧縮と荷重 0 状態までの除圧を、36回繰り返し行い、荷 重および変位を計測した。なお、ここでは最大荷重の $1.0 \%$ (20N)の状態を荷重 0 状態と設定した。

\section{3 断面钼察}

未压縮時、压縮時および復元時の組物の断面観察を行い、 䄉維束の図心を算出し、図心の軌跡より繊維束配向状態を 調べた。前節で述べたように異なる色の繊維束を用いてい るため、繊維束の識別が容易かつ正確となった。断面観察 手順のフローチャートを図 2 に示す。以下、フローチャー ト中の番号に従い説明する。

(1)未圧縮の組物と、最大荷重負荷時に相当する変位量で圧 縮した組物および最大荷重負荷後に荷重 0 状態に相当する 変位量に復元した組物を、不飽和ポリエステル樹脂を用い て包埋する。

(2)包埋した組物を、長手方向に対して直角な面で $1 \mathrm{~mm}$ 毎に 切断研磨する。

(3)各断面をデジタルスキャナを用いて、デジタル画像とし てパーソナルコンピューターに取り込む。取り込んだ画像 の一例を図中に示す。

(4)取り込んだ画像を、画像処理ソフトPhotoShop (Adobe 社 製)を用いて、色付き瀻維束部分のみを抽出し、対象とす る䋐維束断面領域を白で、その他を黒で色分けする。色分 け後の画像の一例を図中に示す。

(5)図心座標解析ソフトを用いて、色付き繊維束断面の図心 座標を得る。

(6)図心座標およびサンプリング閒隔 $(1 \mathrm{~mm})$ より、緎維束の 図心座標值が決定される。得られた図心座標を直線で補完 することにより緎維束配向状態を可視化することが可能 となる。
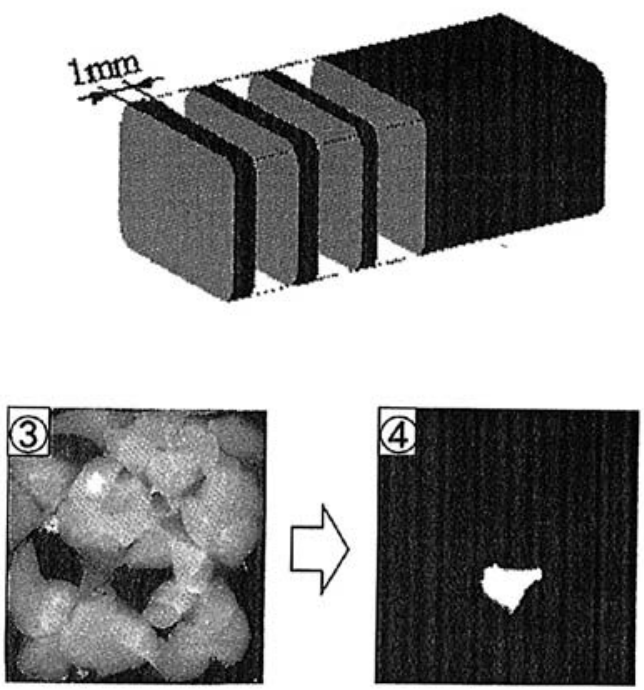

Fig. 2 Flowchart for 3 dimensional construction of fiber orientation. 


\section{3. 実検結果}

\section{1 压縮・復元特性}

図 3 に、側面拘束なし圧縮試験における代表的な圧縮・ 復元曲線を示す。圧縮曲線は初回の圧縮において、変位の 増加に对して荷重が緩やかに増加する領域(領域 1) と、変 位の増加に対して荷重が急激に増加する領域 (領域 2)より 構成され、初回と 2 回目以降の压縮曲線は大きく異なる。 これに対して復元曲線は、少量の変位に対して荷重が急激 に低下する領域のみから構成される。2 回目以降の復元曲 線は、同一の復元曲線に収斂する傾向を有する。

図 4 に復元率と圧緶回数の関係を示す。図中に示すよう に圧縮曲線における荷重 0 から最大圧縮時までの変位量を 圧縮量 $I_{c}$ とし、復元曲線における最大荷重から荷重 0 まで の変位量を復元量 $I_{r}$ とする。復元率は $I_{r}$ を $I_{c}$ で除した值 であると定義する。復元率は、初回圧縮時においては約 $30 \%$ であるが、2 回目の圧縮では 85\%となり、以後 $100 \%$ 付近で ほぼ一定となる。したがって、角打組物江側面拘束なし条 件下において、一度圧縮される事で、復元率は増加して一 定となる。この挙動は、グランドパッキンを側面拘束なし 条件で使用する際、初回圧縮時には復元量が小さくかつ、 永久ひずみを発生する事で相手面の凹凸に対して密着状 態を形成し易くすると共に, 初回圧縮後に加圧面間距離が 変化した際に、グランドパッキンは復元することで引き続 き密着状態を維持できる事を示している。

\section{2 織維束配向状態}

\section{2.1 断面写真钼察}

図 5 に未圧縮時、圧縮時および復元時組物の断面観察よ り得られた、断面写真を示す。図中の上下方向は、压縮負 荷方向である。まず、圧縮時において、経路 b の緎維束 (以 下繊維束 $\mathrm{b}$ とする) が表面を形成している厚さ方向の中央 部分と経路 a の緎維束（以下緎維束 a とする）が表面を形 成する角部の変形は異なることを示している。末圧縮時の 角打組物の中央部分は幅方向に少量突出した形状で完全 な正方形ではない。この組物を圧縮すると、厚さ方向に寸 法が減少する。この時の変形は前報で報告した挙動と同様

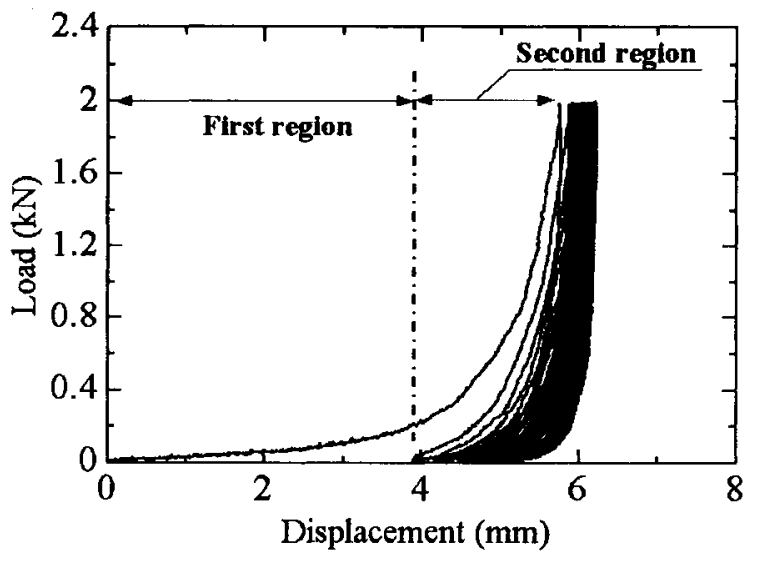

Fig. 3 Load-displacement curve for flat compression test.
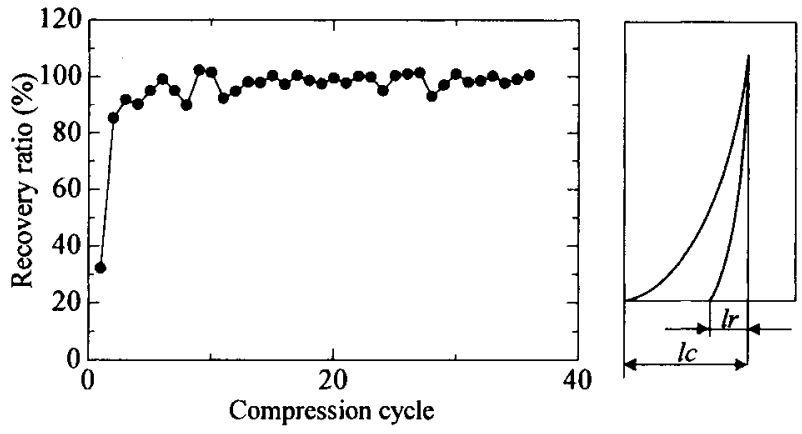

Fig. 4 Relationship between recovery ratio and flat compression cycle.

であり、中央部分の繊維束 $\mathrm{b}$ は幅方向に変形して、より大 きく広がる。これに対して、纎維束 $\mathbf{a}$ が表面を形成する角 部においては幅方向への寸法変化は小さい。復元時には、 加圧方向である厚さ寸法が增加する挙動を示す。ただし、 この初回の復元では前述した永久ひずみを発生するため、 未压縮状態の厚みまでには復元しない。一方、幅方向の寸 法変化はほとんど発生していないことを示している。

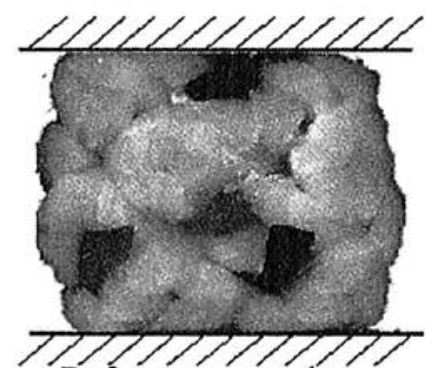

Before compression

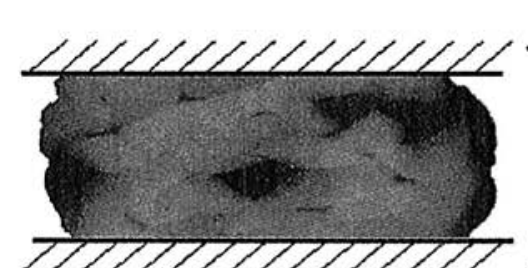

After compression

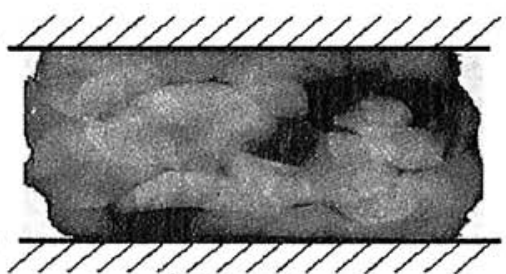

Recovery

Fig. 5 Deformation of cross section for square braided 


\subsubsection{3 次元座標における图心軌跡}

䋐維束配向状態を定量的に表すために、紻維束 a の未圧 縮時、圧縮時および復元時の絨維束断面より算出した䋐維 束断面の図心を 3 次元座標上にプロットし、長手方向に結 んだ軌跡を図 6 に示す。同様に図 7 は緎維束 b の繊維束断 面図心の軌跡を示している。この 3 次元グラフのXY 平面 上における太線は、組物断面形状を長方形化して示してお り、圧縮前、圧縮後および復元後ではこの断面が $X$ 方向、 Y方向に変形していることがわかる。

\section{2.32 次元平面における図心軌跡}

次に、䋐維束配向状態の変化をより良く解釈するために、 各 3 次元グラフにおける絨維束断面の図心軌跡を $\mathrm{XZ、YZ、}$ XY の各平面に投影した軌跡について検討する。この二次元 平面への投影処理は、前報では行わなかったものである。 本項では定性的事項について述べ、定量的なことは次項に て述べる。図 8(a)に、未圧縮時における絨維束 a $の$ 断面の 図心軌跡を XZ、YZ、XY の各平面に投影した軌跡を示す。 㵶維束 $\mathrm{a}$ においては、XY 平面図に示すように、対向する角 部を結ぶ 2 直線より構成され、XZ、YZ平面投影図において はジグザグに配向していることが明らかである。また、繊 維束は組物内部から組物表面へ現われる点で折り返して いる。このため角部で折り返している繊維束 aは、折り返 し点が XZ、YZ 平面投影図において、同じ Z 座標に現われ る。図 8(b)に、未圧縮時における緎維束 b の断面の図心軌 跡を XZ、YZ、XY の各平面に投影した軌跡を示す。 $X Y$ 平面
投影図における図心軌跡は、比較的短い 2 辺および長い2 辺から構成され、組物内部から組物表面に現われる4 筒所 で折り返している。XZ, YZ 平面投影図では、ジグザグに配 向し、折り返し点がこの両平面投影図において異なるZ座 標に現われる。

図 9 (a)に、圧縮時組物の䄉維束 a の断面の図心軌跡を $X Z 、 Y Z 、 X Y$ の各平面に投影した軌跡を示す。Y方向に圧縮 変形しているため、全体にY軸方向のみ小さくなっている。 未圧縮時と圧縮時の図心軌跡を比較すると、YZ 平面投影 図における直線部分の角度変化を発生している。XY 平面 投影図では直線部分の角度変化に加えて、この直線部分の クリンプが大きくなっている。図 9(b)に圧縮時組物の繊維

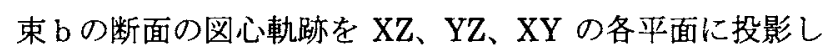
た軌跡を示す。緎維束 $\mathrm{b}$ は $\mathrm{YZ}$ 平面投影図と $X Z$ 平面投影図 においては角度変化のみを発生している。

図 $10(\mathrm{a})$ に、復元時の組物の繊維束 $\mathrm{a}$ の断面図心の軌跡を $\mathrm{XY} 、 Y Z 、 X Z$ の各平面に投影した軌跡を示す。組物はY 方向 に復元しているが、繊䧽束 $\mathrm{a} の$ 図心軌跡の直線部分の角度 $\alpha$ の変化は小さく、クリンプが変化して小さくなる。図 10 (b)に、復元時組物の緎維束 b $の$ 断面の図心軌跡をXY、 $\mathrm{YZ} 、 \mathrm{XZ}$ の各平面に投影した軌跡を示す。緎維束 b は、組物 の幅方向であるX 方向に変化しないが、厚み方向であるY 軸方向に繊維束直線部分の角度が変化してY軸方向の寸法 が大きくなる。

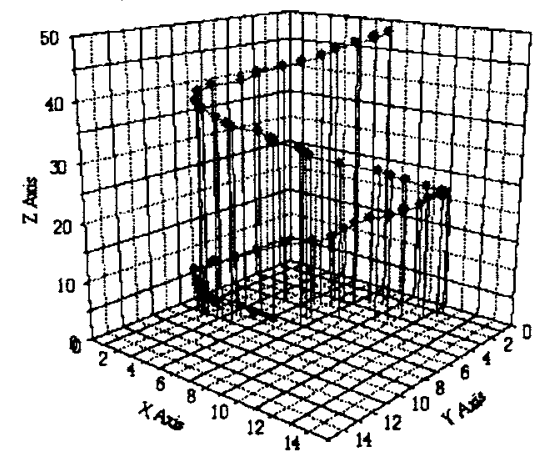

Before compression

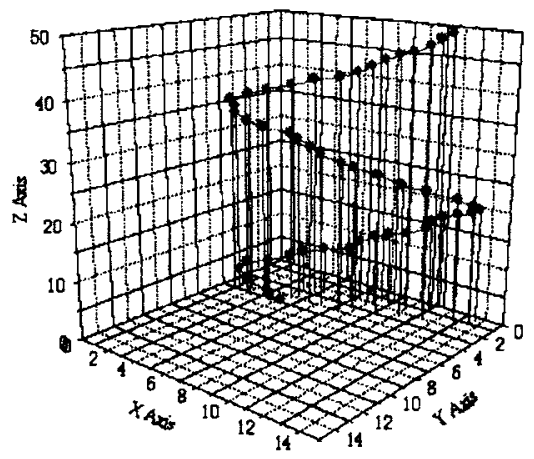

After compression

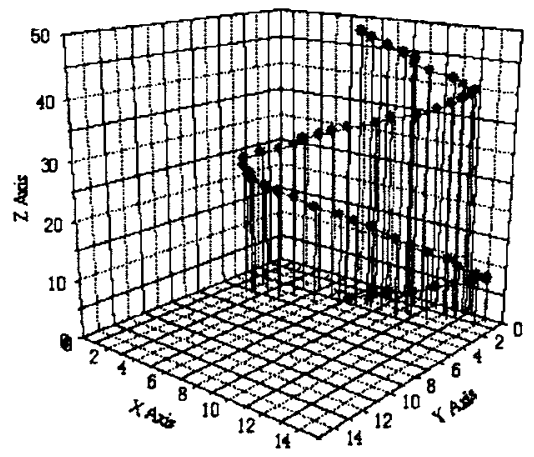

Recovery

Fig. 6 The 3D path of the centroid for fiber bundle $a$.

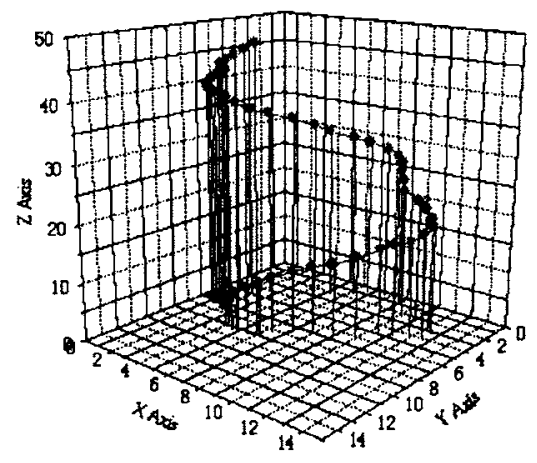

Before compression

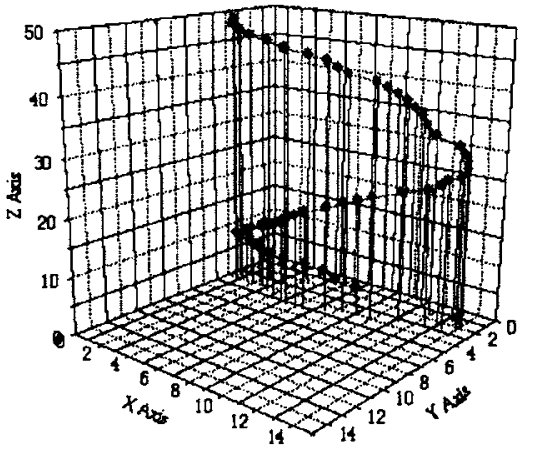

After compression

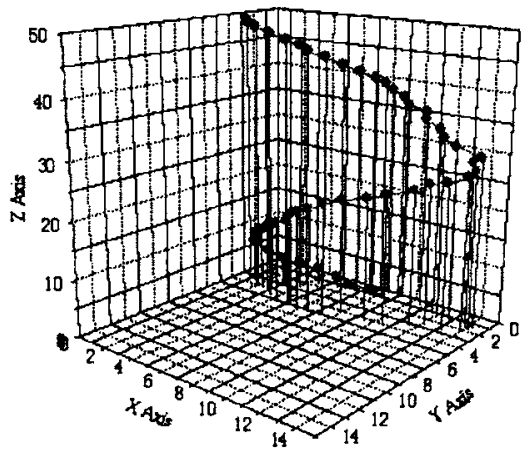

Recovery

Fig. 7 The 3D path of the centroid for fiber bundle $\mathbf{b}$. 

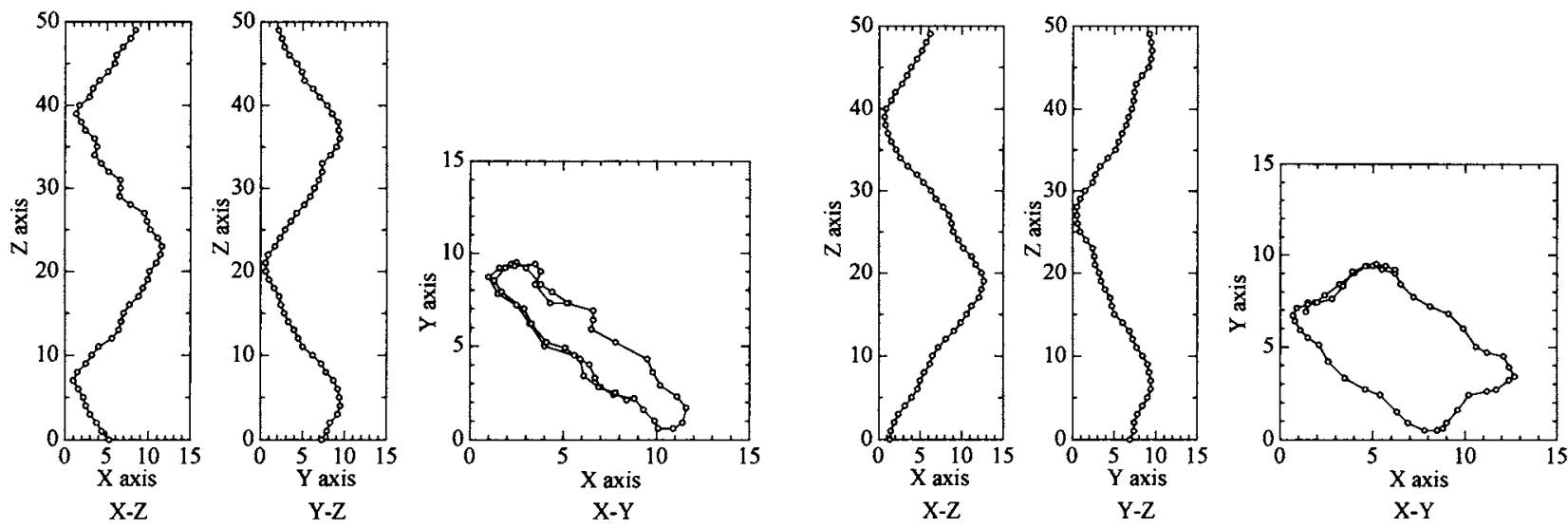

(a)

(b)

Fig. 8 The path of the centroid for fiber bundle before compression.
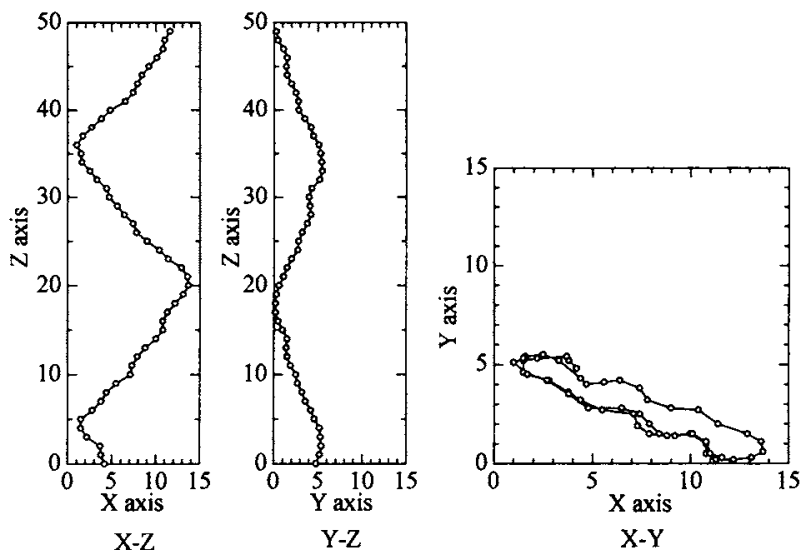

(a)

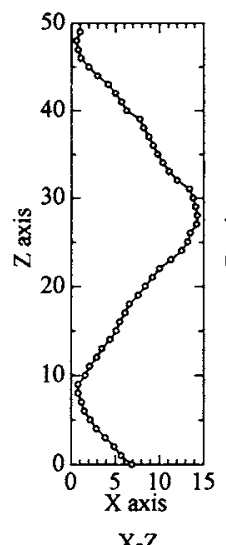

$\mathrm{X}-\mathrm{Z}$

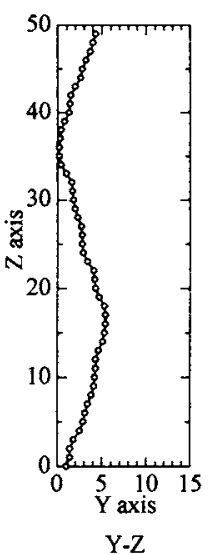

(b)

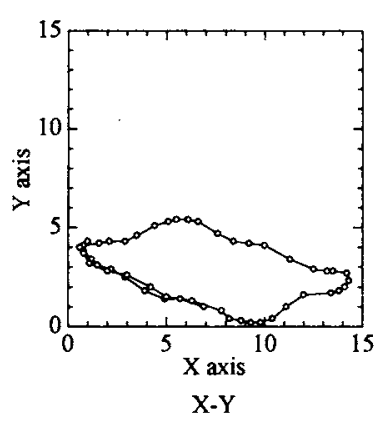

(b)

Fig. 9 The path of the centroid for fiber bundle after flat compression .
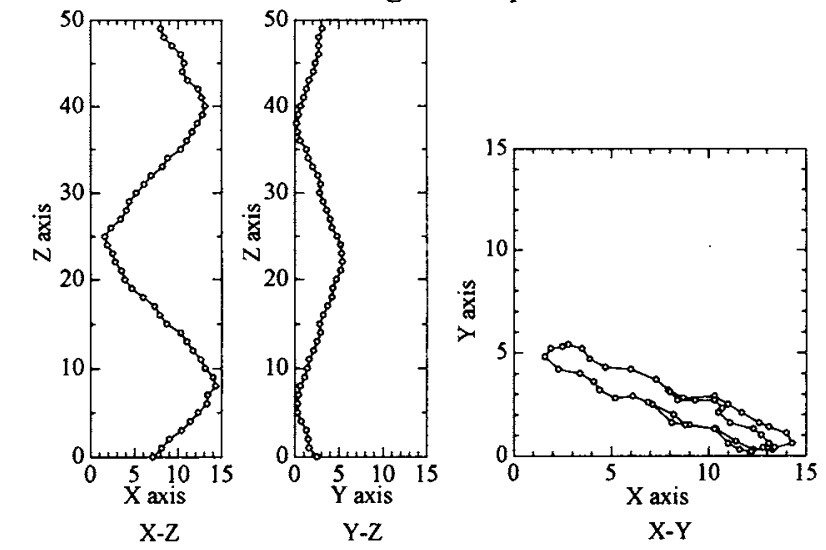

(a)
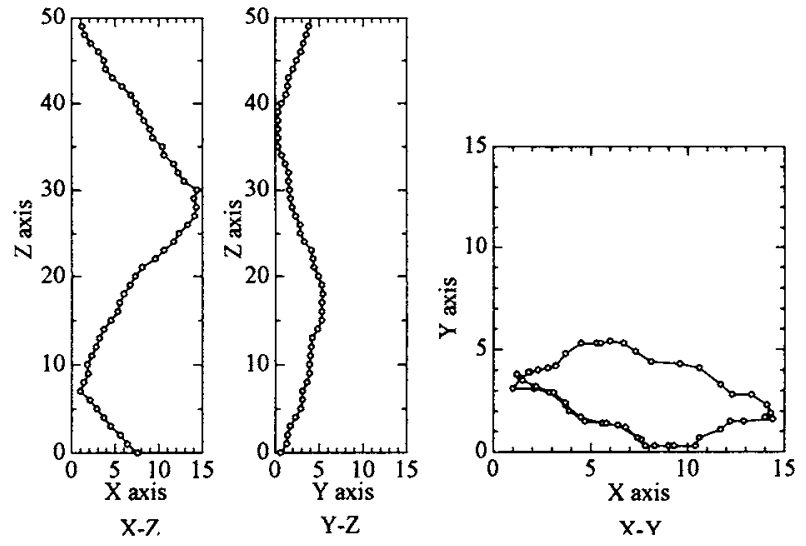

(b)

Fig. 10 The path of the centroid for fiber bundle after recovery.

\subsubsection{3 次元座標におけるクリンプ係数}

前項では定性的なことについて述べたが、本項では定量 的なことについて検討する。各図心の 3 次元座標より、各 経路ごとの絨維束配向状態を定量的に把握するために、織 維束のうねり度合いを示すクリンプ係数、および、䋐維束 配向角度を算出した。なお、このクリンプ係数および縅維 束配向角度は、繊維束がジグザグに配向している折り返し 部、すなわち、表面形成領域を除き、組物内部の緎維束断 面の図心データを利用して算出した。クリンプ係数とは、
所定区間の瀻維束断面の図心において、複数の隣りあう図 心間距離の総和を、起点の断面㘠心と終点の断面図心間の 直線距離で除した值である。表 1 に、クリンプ係数の算出 結果を示す。瀻維束 $\mathrm{a}$ のクリンプ保数は圧縮前 1.037 であ ったのが圧樎時に 1.048 に増加するが、復元時には 1.036 に減少して未圧縮時と同等のクリンプ係数になる。緎維束 b に関しては、未圧縮時は 1.029、圧縮時 1.029、そして復 元時 1.024 とほとんど変化しない。 
Table 1 Change in crimp ratio

\begin{tabular}{cccc}
\hline & $\begin{array}{c}\text { Before } \\
\text { compression }\end{array}$ & $\begin{array}{c}\text { After } \\
\text { compression }\end{array}$ & Recovery \\
\hline $\mathrm{a}$ & 1.037 & 1.048 & 1.036 \\
$\mathrm{~b}$ & 1.029 & 1.029 & 1.024 \\
\hline
\end{tabular}

Table 2 Change in projected braiding angle.

\begin{tabular}{|c|c|c|c|c|}
\hline & & $\begin{array}{c}\text { Before } \\
\text { compression }\end{array}$ & $\begin{array}{c}\text { After } \\
\text { compression }\end{array}$ & Recovery \\
\hline$\theta \mathrm{yz}$ & $\begin{array}{l}a \\
b\end{array}$ & $\begin{array}{l}31.5 \\
25.2\end{array}(6.3)$ & $\begin{array}{l}15.0 \\
12.6\end{array}{ }^{(2.4)}$ & $\begin{array}{l}18.4 \\
17.9\end{array}(0.5)$ \\
\hline$\theta x y$ & $\begin{array}{l}a \\
b\end{array}$ & $\begin{array}{l}41.4 \\
34.5\end{array}(6.9)$ & $\begin{array}{l}18.7 \\
16.9\end{array}(1.8)$ & $\begin{array}{l}22.2 \\
21.7\end{array}(0.5)$ \\
\hline
\end{tabular}

\section{Compression}

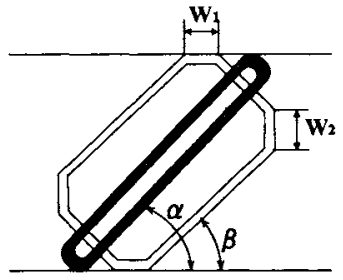

$\alpha \gg \beta$

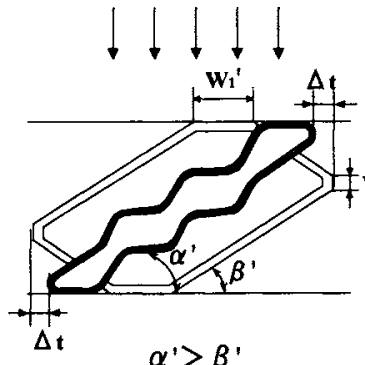

$\alpha^{\prime}>\beta^{\prime}$

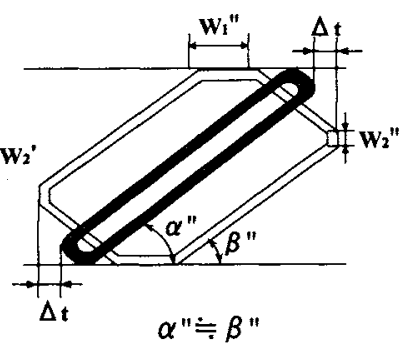

(c) Recovery

$\begin{array}{ll}\text { (a) Before compression } & \text { (b) After compression }\end{array}$

Fig. 11 Model of deformation for fiber bundle path (projected X-Y plane).

\subsection{5 緎維束配向角度}

組物内部における絨維束配向角度の変化について検討 した。緎維束配向角度の算出方法は前報 [1] と同じである。 表 2 に各投影面における緉維束の配向角度を示す。 $\theta \mathrm{yz}$ は末圧縮時に綫維束 a $31.5^{\circ}$ 、繊維束 b が $25.2^{\circ}$ とそ の差が $6.3^{\circ}$ であるのに対して、压縮時には各々 $15.0^{\circ}$ と $12.6^{\circ}$ に減少して、その差は $2.4^{\circ}$ と減少する。一方、復 元時には各々 $18.4^{\circ}$ と $17.9^{\circ}$ と增加して、その差は $0.5^{\circ}$ とさらに小さくなる。 $\theta \mathrm{xy}$ に関しては、未圧縮時に緎維束 a と繊維束 $\mathrm{b}$ に存在していた角度差 $6.9^{\circ}$ が、圧縮時には $1.8^{\circ}$ に変化して、復元時には $0.5^{\circ}$ とさらに等しくなる. 側面拘束無しの条件下で圧縮および復元を繰り返すこと で、两緘維束は配向角度が等しい䋐維束配向状態へと移行 したと考えられる。

\section{4. 考 察}

以上の結果より、明らかとなった側面拘束無し条件下で の圧縮と復元における繊維束配向状態の変形モデルを図 11 に示す。(a) 怄末圧縮時の絨維束 $\mathrm{a}$ と繊維束 $\mathrm{b} の X Y$ 平面 への投影図である。

織維束 $\mathrm{a}$ は組物角部の変曲点 2 箇所において表層部に現 われるほかは、組物内部の対角線上に存在している。これ に対して繊維束 $\mathrm{b}$ 注組物表面の変曲点 4 简所において、表 層部に現われる。この繊維束に圧縮力が作用した時、䋐維 束 $\mathrm{a}$ は組物厚みが小さくなることで、加圧面との角度 $\alpha$ が 小さくなるとともにクリンプが增加する。これに対して絨 維束 $\mathrm{b}$ は、加圧面との傾斜角 $\beta$ が小さくなるとともに、組 物表面に現われている部分の繊維束接触幅Wも変化する。 に厚み寸法のみが増加する復元挙動を示す。この変形に伴 い、圧縮前の供試体においては配向角度が異なっていた織 維束 $\mathrm{a}$ と繊維束 $\mathrm{b}$ の傾斜角 $\alpha$ と傾斜角 $\beta$ の差が小さくなる。
加圧面に接しているW1 は大きくなるが、側面の表層部は 接触による拘束がなく自由に変形して、幅方向に突出する ためW2 は小さくなる。そして復元時には、緎維束 a と緎 維束 $\mathrm{b}$ の角度変化を発生するとともに、繊維束 $\mathrm{a}$ のクリン プ係数が末圧縮時の状態になることで、幅寸法は変化せず に厚み寸法のみが増加する復元挙動を示す。この変形に伴 い、王縮前の供試体においては配向角度が異なっていた䋐 維束 $\mathrm{a}$ と䋐維束 $\mathrm{b}$ の傾斜角 $\alpha$ と傾斜角 $\beta$ の差が小さくなる。

\section{5. 結 論}

1）角打組物に繰り返し圧縮負荷を与えた場合の復元率 は、初回圧樎と 2 回目以降の圧縮では著しく異なる変形举 動を示す。初回圧縮時には、永久ひずみを発生する復元挙 動を示すのに対して、2 回目以降の圧縮では、一度圧縮さ れる事で復元率は、增加して $100 \%$ に近い値に収斂して安 定する。

2）未圧樎時に異なっていた瀻維束 $\mathrm{a}$ と繊維束 $\mathrm{b} の$ 配向角 度は、圧縮・復元の過程を経過する事で、同一角度に変化 してより安定な繊維束配向状態に移行する。

3）角打組物の復元は、䋐維束 $\mathrm{a}$ と䋐維束 b において発生

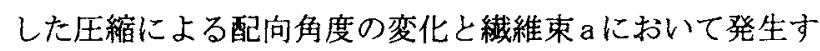
るクリンプの変化が元に戻るうとすることで発生する。

\section{文 献}

1. T. Ueda, A. Ohtani, A. Nakai, H. Hamada, Y. Fujii, Sen'i Gakkai, 59, 273 (2003).

2. T. Ueda' M. Sakaguchi, H. Hamada, Sen'i Gakkai Preprints, G-100 (1999). 